Vol.4 No.3

\title{
IbM KELOMPOK USAHA RUMAH MAKAN DI KELURAHAN RANOTANA KECAMATAN SARIO KOTA MANADO
}

\section{Imelda W J Ogi}

Fakultas Ekonomi dan Bisnis Universitas Sam Ratulangi A R T I C LE INFO

\author{
Keywords : entrepreneurship, MEA, business \\ management
}

Kata Kunci: kualitas produk, kepuasan pelanggan

\begin{abstract}
The purpose of this training is to provide knowledge and skills in developing business of culinary entrepreneur in Kelurahan Ranotana Kecamatan Sario Manado city. Analytical techniques descriptive analysis is used. The perpetrators of micro enterprises and small and medium business in particular the eating houses located in the area Kel. Ranotana Kec. Sario Manado material provided with the role and function of the MEA, so that they can develop their enterprises to be able to compete with foreign companies incorporated in the MEA which can easily develop their enterprises in the province North Sulawesi, especially in Manado city. this devotion In business are also provided with entrepreneurial training so as to help the businessmen in their efforts so that qualify have competitiveness and can compete with the big businessmen
\end{abstract}

Abstrak :Tujuan pelatihan ini adalah untuk memberikan pengetahuan dan keterampilan dalam mengembangkan usaha rumah makan di Kelurahan Ranotana Kecamatan Sario Kota Manado. Teknik analisis yang digunakan adalah analisis deskriptif. Para pelaku usaha mikro dan kecil menengah khususnya usaha rumah makan yang berada di daerah Kel. Ranotana Kec. Sario Kota Manado dibekali dengan materi peran dan fungsi dari MEA, sehingga mereka dapat mengembangkan usaha mereka untuk dapat bersaing dengan perusahaan-perusahaan asing yang tergabung dalam MEA yang dapat dengan mudah mengembangkan usaha mereka di propinsi Sulawesi Utara khususnya di Kota Manado.Dalam pengabdian ini para pelaku bisnis juga dibekali dengan pelatihan kewirausahaan sehingga dapat membantu para pelaku usaha dalam memanajemen usaha mereka sehingga mempunyai daya saing dan dapat bersaing dengan para pelaku usaha besar. 


\section{Latar Belakang}

\section{PENDAHULUAN}

Pertumbuhan ekonomi yang cukup stabil pada tahun-tahun terakhir memang mulai membawa angin kebangkitan di berbagai bidang usaha di Indonesia, meskipun intaian krisis masih harus terus diwaspadai. Usaha rumah makan juga terus berkembang, hal ini ditandai dengan mulai bermunculan banyak rumah makan baru, baik rumah makan mahal, maupun rumah makan yang membidik pasar dengan ekonomi menengah dan ekonomi bawah.

Di kota Manado sendiri pertumbuhan bisnis makanan dan minuman masih tercatat sebagai pertumbuhan yang tinggi. Berbagai outlet yang menawarkan produk makanan dan minuman dalam berbagai bentuk banyak bermunculan. Mulai dari yang sederhana hingga yang mewah. Dimana hal ini disebabkan karena makanan adalah salah satu kebutuhan pokok yang harus dipenuhi setiap hari oleh manusia.

Kawasan Kecamatan Sario merupakan salah satu daerah yang berada di kota Manado yang tingkat pertumbuhan usaha rumah makan terlihat sangat signifikan dimana dapat dilihat di sepangjang ruas jalan Kecamatan Sario dipenuhi dengan usaha ini. Khususnya di daerah lorong Ranotana usaha rumah makan merupakan primadona bagi masyarakat kota Manado dan daerah sekitar kota Manado bahkan bagi pelancong yang berasal dari luar daerah menjadikan pilihan utama untuk mencari wisata kuliner, hal ini membuat para pelaku usaha rumah makan yang bersekala mikro kecil dan menengah untuk bisa memanajemen usaha mereka dengan lebih baik sehingga dapat bersaing dengan usaha-usaha rumah makan yang berskala besar.

Seiring dengan perkembangan dunia bisnis ini para pelaku bisnis dihadapkan pada persaingan global lebih khusus dalam penerapan Masyarakat Ekonomi Asean (MEA) yang sudah mulai dilaksanakan pada tahun 2016 ini. Dimana untuk menghadapi persaingan ini dituntut bagi setiap pelaku bisnis lebih khusus usaha mikro dan usaha kecil menengah untuk mampu bersaing dengan pelaku-pelaku bisnis yang masuk di dalam keanggotaan MEA yang dengan mudah untuk membangun bisnis atau usaha mereka di daerah Sulawesi Utara lebih khusus di Kota Manado.

Para pelaku bisnis juga dituntut untuk mampu memanajemen usaha mereka kearah yang lebih professional sehingga mereka mampu menghasilkan produk-produk yang lebih berinovasi, serta dapat memberikan pelayanan yang lebih baik.

\section{Kewirausahaan}

\section{TINJAUAN PUSTAKA}

Karakteristik kewirausahaan merupakan kualitas atau sifat yang tetap terus menerus dan kekal yang dapat dijadikan ciri untuk mengidentifikasikan seorang pribadi, suatu objek, suatu kejadian, intergrasi atau sintesis dari sifat-sifat individual dalam bentuk suatu atau kesatuan dan kepribadian seseorang, dipertimbangkan dari titik pandangan etis dan moral. Sementara sikap kewirausahaan adalah sikap seseorang yang mempunyai n-ach yang tinggi dari kehidupan sehari-hari atau ciri-ciri sikap seorang wirausaha (Faisal, 2002). Dalam kenyataannya, perusahaan itu merupakan sebuah produk dari beberapa lingkungan. Sedangkan untuk mempertahankannya, perusahaan harus dapat menyesuaikan dengan kondisi lingkungan yang berubah-rubah. Lingkungan merupakan segala sesuatu yang berada di luar organisasi (Robbins, 2008). Lingkungan tidak sebatas lingkungan, namun terdapat lingkungan eksternal, lingkungan industri dan lingkungan internal. Lingkungan eksternal terdiri dari unsurunsur yang berada di luar organisasi, yang relevan terhadap kegiatan organisasi itu (Stoner,1996). Lingkungan industri memiliki pengaruh yang lebih langsung terhadap daya saing strategis dan laba di atas ratarata. Intensitas persaingan industri dan potensi laba industri merupakan fungsi dari lima kekuatan kompetitif dan lingkungan internal ini dimungkinkan untuk dikendalikan oleh para pelaku bisnis, sehingga dapat diarahkan sesuai dengan keinginan perusahaan dalam upaya meningkatkan pertumbuhan usaha. Menurut Suprapto (dalam Setiawan, 2010) pertumbuhan perusahaan adalah peningkatan ukuran usaha dan adanya ekspansi operasi perusahaan melalui pengelolaan kekuatan yang ada dalam perusahaan dalam kurun waktu tertentu. 


\section{Pemasaran}

Kotler, (2007): menyatakan bahwa " pemasaran adalah suatu proses sosial dan manajerial di mana individu dan kelompok mendapatkan kebutuhan dan keinginan mereka dengan menciptakan, menawarkan, dan bertukar sesuatu yang bernilai satu sama lain. Definisi pemasaran ini bersandar pada konsep inti: kebutuhan (needs), keinginan (wants), dan permintaan (demands); produk (barang, jasa dan gagasan); nilai, biaya dan kepuasan; pertukaran, transaksi dan hubungan; pasar dan pemasaran serta pemasar. Banyak yang menganggap bidang ini identik atau sama dengan bidang penjualan. Sesungguhnya pemasaran memiliki arti yang luas daripada penjualan. Bidang penjualan merupakan bagian dari bidang pemasaran, sekaligus merupakan bagian terpenting dari bidang pemasaran itu sendiri. Pemasaran berarti bekerja dengan pasar untuk mewujudkan pertukaran potensial dengan maksud memuaskan kebutuhan dan keinginan manusia. Jika perusahaan menaruh perhatian lebih banyak untuk terus menerus mengikuti perubahan kebutuhan dan keinginan baru, mereka tidak akan mengalami kesulitan untuk mengenali peluang-peluangnya. Karena para konsumen selalu mencari yang terbaik untuk kehidupannya dan tentu saja dengan harga yang terjangkau dan dengan kualitas yang baik pula, hal itulah yang memicu adanya persaingan yang semakin tajam yang menyebabkan para penjual merasa semakin lama semakin sulit.

\section{Pengertian Konsep Pemasaran}

Definisi menurut Basu Swastha (2002:17) Konsep pemasaran adalah sebuah falsafah bisnis yang menyatakan bahwa pemuasan kebutuhan konsumen merupakan syarat ekonomi dan sosial bagi kelangsungan hidup perusahaan. Konsep pemasaran didasarkan pada pandangan dari luar ke dalam. Konsep ini diawali dengan mendefinisikan pasar yang jelas berfokus pada kebutuuhan pelanggan, memadukan semua sistem kegiatan yang akan memengaruhi pelanggan dan menghasilkan laba melalui

pemuasan pelanggan. Konsep pemasaran bersandar pada empat pilar utama.

1. Pasar sasaran tidak ada perusahan yang dapat beroperasi disemua pasar dan memuaskan semua kebutuhan dan juga tidak ada yang dapat beroperasi dengan baik dalam pasar yang luas, sehingga jika suatu perusahaan itu ingin berhasil maka ia harus dapat mendefinisikan pasar sasaran meraka dengan cermat dan menyiapkan program pemasaran.

2. Kebutuhan pelanggan, memahami kebutuhan dan keinginan pelanggan tidak selalu merupakan tugas yang sederhana dikarekan beberapa pelanggan itu memiliki kebutuhan sendiri yang tidak mereka sadari atau mereka tidak dapat mengutarakan kebutuhan-kebutuhan ini.

3. Pemasaran terpadu, jika semua departemen bekerja sama melayani kepentingan pelanggan maka hasilnya adalah pemasaran terpadu. Pemasaran terpadu berjalan dalam dua tahap

yaitu :

a. Tahap Pertama : beragam fungsi pemasaran, tenaga penjualan periklanan, manajemen produk, riset pemasaran dan lainnya harus bekerja sama.

b. Tahap Kedua : pemasaran harus dikoordinasikan dengan baik pada bagian lain perusahaan.

c. Profitabilitas, tujuan utama konsep pemasaran adalah membantu organisasi mencapai tujuan mereka.

\section{METODE PENELITIAN}

Disain penelitian ini adalah deskriptif dan merupakan hasil dari pelaksanaan IbM penulis. Responden adalah Kelompok Usaha Rumah Makan Di Kelurahan Ranotana Kecamatan Sario. Teknik analisis yang digunakan adalah analisis deskriptif.Metode pelaksanaan yang digunakan dalam mendukung realisasi program ini adalah dengan mengadakan sosialisasi atas pentingnya MEA dan pemahaman tentang kewirausahaan. Sedang asumsi dasar program ini adalah bahwa penduduk yang melakukan usaha rumah makan di Kec. Sario yang menjadi target dan belum pernah mendapatkan sosialisasi ini, mereka sangat membutuhkan informasi dan pengetahuan ini. Lingkup batasan penerapan program adalah, memberikan sosialiasasi pada kelompok mitra dengan tujuan (1) Kelompok mitra mampu bersaing dalam eraglobalisasi terlebih memasuki MEA. Program diterapkan dengan cara sosialiasi dan diskusi tentang tantangan memasuki era MEA, (2) memberikan pengetahuan dan keterampilan dalam berwirausaha. 


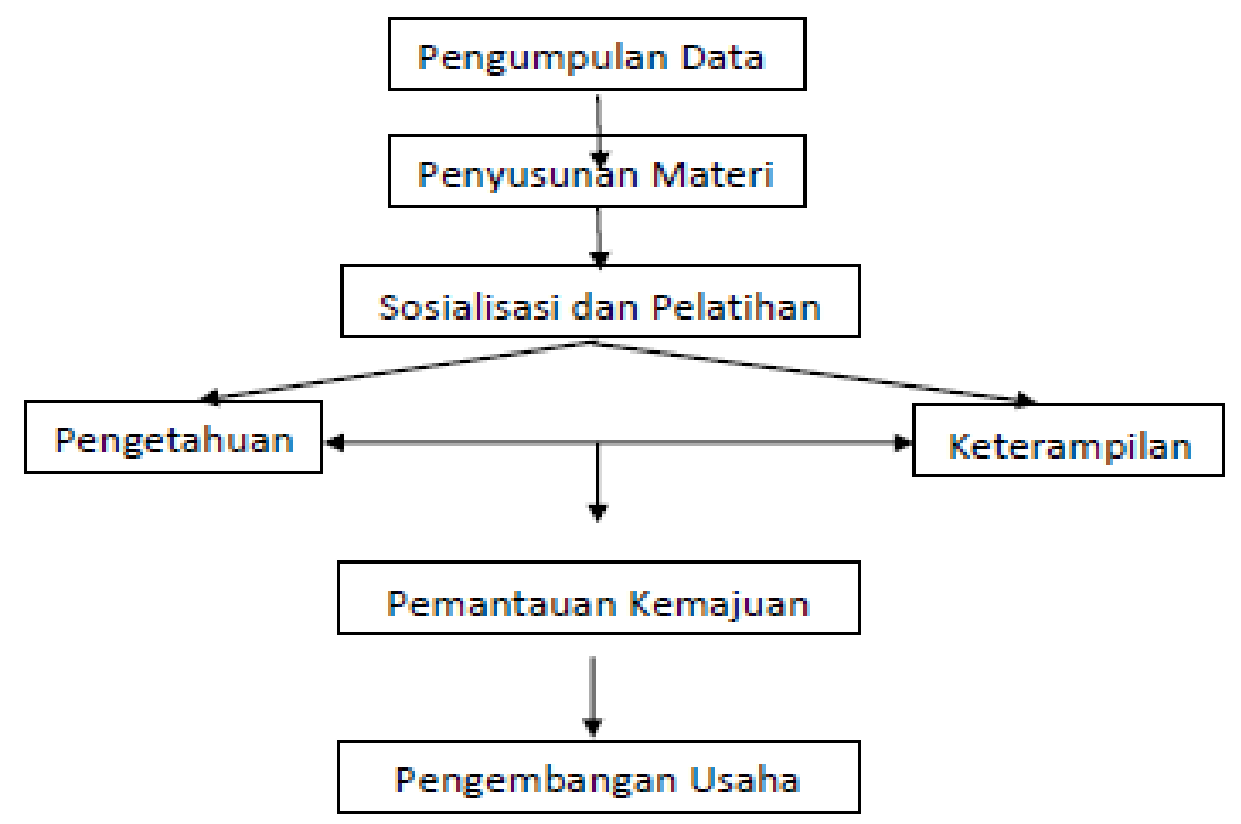

Gambar. 1. Pendekatan (Kerangka) dan materi dalam penanganan masalah mitra

\section{HASIL DAN PEMBAHASAN}

Kegiatan pengabdian telah dilaksanakan dengan mengundang para pemilik rumah makan yang berada di sekitar Kelurahan Ranotana. Kegiatan bagi kelompok pemilik rumah makan dibagi dalam dua sesi, mengingat penyesuaian waktu yang dilakukan pemilik usaha. Melalui kegiatan pengabdian ini para pelaku usaha mikro dan kecil menengah khususnya usaha rumah makan yang berada di daerah Kel. Ranotana Kec. Sario Kota Manado dibekali dengan materi peran dan fungsi dari MEA, sehingga mereka dapat mengembangkan usaha mereka untuk dapat bersaing dengan perusahaan-perusahaan asing yang tergabung dalam MEA yang dapat dengan mudah mengembangkan usaha mereka di propinsi Sulawesi Utara khususnya di Kota Manado.Dalam pengabdian ini para pelaku bisnis juga dibekali dengan pelatihan kewirausahaan sehingga dapat membantu para pelaku usaha dalam memanajemen usaha mereka sehingga mempunyai daya saing dan dapat bersaing dengan para pelaku usaha besar.

Untuk memajukan sebuah usaha dibutuhkan keterampilan dan pengetahuan yang mumpuni dari para pelaku usaha tersebut. Sehingga impelementasi dari pelatihan ini diharapkan dapat diwujudkan dalam beberapa hal seperti ; mempersingkat masa belajar untuk memenuhi standar kinerja yang ditentukan. Dengan mengikuti pelatihan, para pengusaha mempunyai pengetahuan yang cukup untuk menjalankan bisnis mereka sehingga mereka dapat bekerja secara optimal, tanpa harus meraba-raba terlebih dahulu langkah apa yang harus dilakukan dan dapat memaksimalkan waktu yang ada, meningkatkan kinerja pekerjaan. Pelatihan bertujuan untuk meningkatkan kinerja dalam menghadapi pekerjaan-pekerjaan yang sedang dihadapi, sehingga menjadi lebih efektif dan efisien, serta dapat menghasilkan inovasi-inovasi baru bagi bisnis mereka. Kemudian, adanya pembentukan sikap pelatihan diharapkan dapat membentuk sikap dan tingkah laku para pengusaha dalam menjalin hubungan baik antar pengusaha, pengusaha dengan patner bisnis, pengusaha dengan karyawan, maupun pengusaha dengan konsumen. 


\section{PENUTUP}

\section{Kesimpulan}

Berdasarkan uraian dalam analisis situasi diatas maka peserta diharapkan memiliki pemahaman tentang pentingnya peranan MEA dalam industri rumah makan berskala mikro kecil dan menengah, dengan adanya pelatihan kewirausahaan dan pengetahuan yang memadai dalam memanajemen usaha.

\section{Saran}

Dari masalah pembahsan maka dipandang perlu untuk dilakukan sosialisasi ataupun pelatihan peran MEA dan pelatihan kewirausahaan kepada para pelaku bisnis rumah makan khususnya yang berada di Kelurahan Ranotana secara berkesinambungan sehingga terus melatih kemampuan dan memberikan pengetahuan bagi para pelaku usaha dalam meningkatkan usahanya.

\section{DAFTAR PUSTAKA}

Kotler Philip, Kevin Lane Keller, Manajemen Pemasaran, Alih Bahasa Benyamin Molan, Jilid Satu, Cetakan Kedua, Jakarta : Indeks, 2007

Robbins. Stephen. P. (2010). Manajemen. Edisi kedelapan. Jilid 2. Jakarta: PT. Indeks.

Faisal. 2002. Kalau Begitu, Saya Berani Berwirausaha. Jakarta: Bina Rena Pariwara. 